\title{
Fázisátalakulások és belső feszültségek
}

\section{Johanyák Edit}

A dolgozat bemutatja a belső feszültségek keletkezésének okait, különös tekintettel azokra, amelyek acélok hõkezelésekor maradnak a munkadarabban, valamint rámutat néhány olyan külsõ és belsõ befolyásoló tényezõre, amely nagymértékben meghatározza a munkadarabban visszamaradó feszültségek nagyságát és milyenségét.

A szerkezetek és gépek tervezésekor nagyon fontos, hogy kellő figyelmet szenteljenek a belső feszültségek jelenlétére, mert ezek ismeretében pontosabban lehet méretezni, nō a biztonság és csökken az anyagfelhasználás. A belsõ feszültségek a munkadarabot járulékosan terhelik. A külsō és belső feszültségek összeadódnak és az eredő feszültségi állapot határozza meg a munkadarab ıgénybevételét, alakváltozását, fizikai vagy kémiai tulajdonságait. A belső feszültségek általában többtengelyũek, ami elősegítı a ridegtörésre való hajlamot.

Bizonyos hőkezelési eljárásokkal szándékosan keltünk nagy belsō feszültséget a munkadarabban, mert ezek kedvező eloszlása esetén növelhető a terhelhetőségük (pl. betétedzés, karbonitridálás, más felületi kezelések, felülettömörítő alakítási eljárások ennek következtében növelik a kifáradási határt.) [1]

Hőkezelés közben mindig keletkeznek belsõ feszültségek, amelyek gyakran méretváltozást okoznak, ezért fontos ismerni a belsõ feszültségek keletkezésének okait és azokat a tényezõket, amelyek befolyásolják azt. Az 1. ábrán látható az alkatrész használati tulajdonságait befolyásoló tényezők kapcsolatrendszere hőkezeléskor [1].

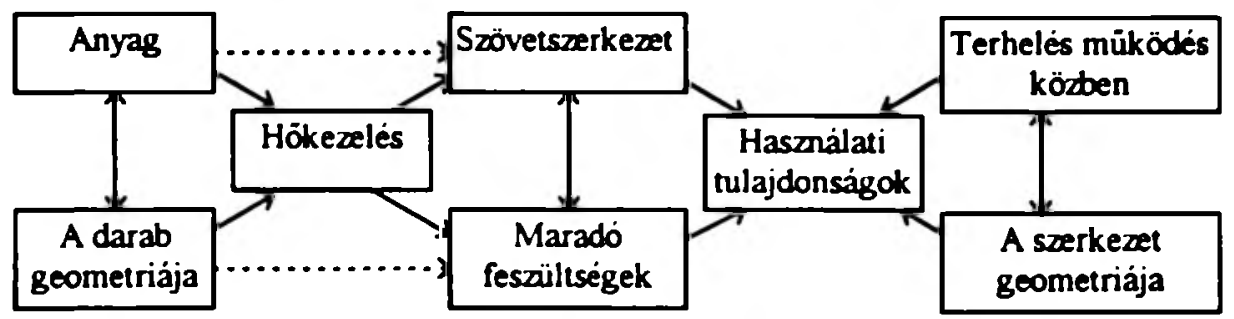

1. ábra

Ha a darabban kis belsō feszültségek ébrednek, ezek nem okozzák a darab méretváltozását, alakváltozását, ezek azonban megmaradnak a darabban, maradó feszültségként. Az ilyen munkadarab egy részének lemunkálása után az egyensúlyi állapot megbomlik és a darab vetemedik. Hőkezelés folyamán a munkadarabokban ébredő feszültségek keletkezésük alapján kétfélék lehetnek: hõfeszültségek és átalakulási feszültségek. 
A höfeszültségek a hötágulás következményei. A fémes anyagok sủrủsége a hömérséklettel változik, ezért az egész tömegében nem egyenletesen hevitett vagy hủtött munkadarabban belső feszültségek ébrednek.

A visszamaradó feszültségek számitására többféle módszert is alkalmaznak, amelyek a darabban a hủtés során végbemenö folyamatok leírásán alapulnak.

$\mathrm{Az} 2$. ábra egy $35 \mathrm{~mm}$-es szobahömérsékleten is ausztenites henger axiális hőfeszültségének változását mutatja az idõ

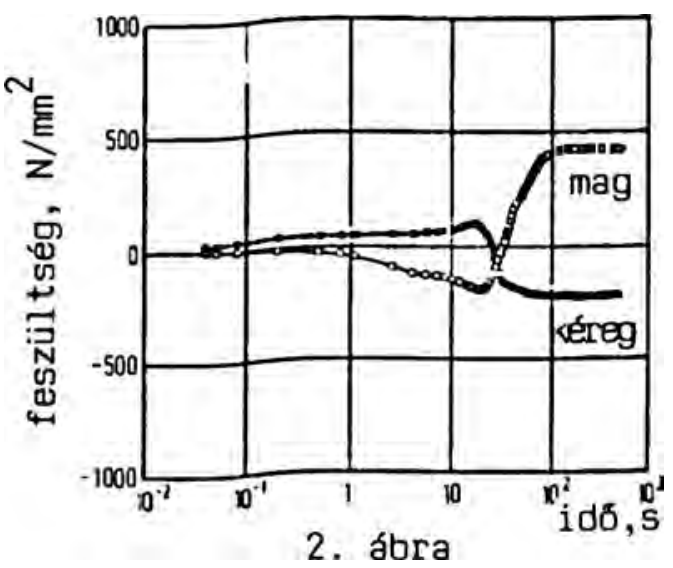
függvényében, vizhütés esetén. Mivel a darabban téffogatváltozást elöidézõ átalakulás nem játszódik le, a hủtés kezdeti fázisában a kéregben (felületen) húzófeszültségek jelentkeznek és a magban pedig nyomófeszültségek ébrednek. Ezek a feszültségek meghaladják az anyag folyáshatárát és a kéreg a maghoz képest megnyúlik (megfolyik). Ahogy a hőmérséklet a kéreg és a mag között kezd kiegyenlitődni a hőfeszültségek lecsökkennek de értékük nem lesz nulla. Mivel a kéreg a maghoz képest megnyúlt magas hỏmérsékleten, a

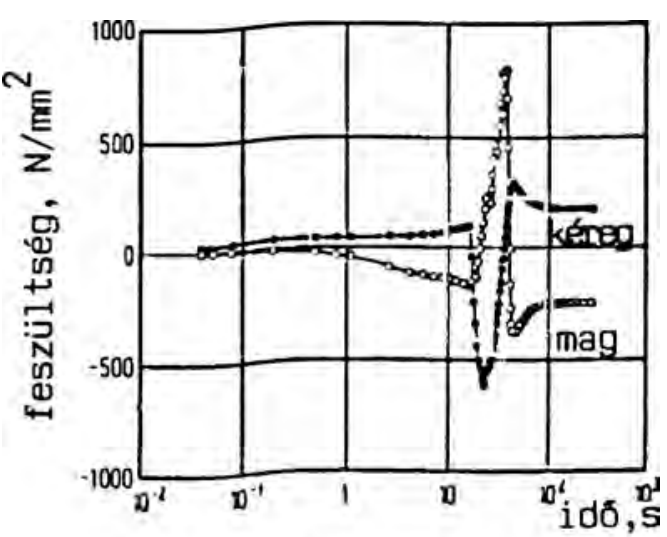

3. ábra következmény az lesz, hogy szobahőmérsékleten a kéregben nyomó-, a magban pedig húzófeszültség fog visszamaradni.

A höfeszültségek nagysága függ $a z$ anyag hôtágulási együtthatójától, a darab méretétõl és a hőmérséklet gradienstöl.

\section{Atalakulási feszültségek}

Szilárd halmazállapotú átalakulások (fázsátalakulások) típusai: - Az egyik fázis úgy alakul át más fázissá, hogy összetétele ugyanaz marad: martenzites átalakulás.

- Új fázis alakul ki, amely összetételében és
4. ábra

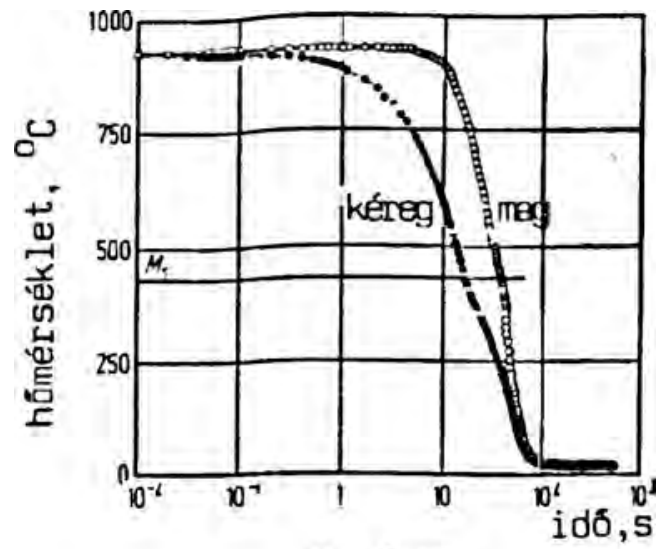
szerkezetében eltér az eredeti fázstól, az eredetı fázis is megmarad: kiválásos reakciók.

- Egy fázis két új fázissá alakul át, és mınd a kettö összetétele eltér az eredetitöl: eutektoidos átalakulás.

- Egy szilárd és egy gáznemủ anyag reakciójából keletkezō új fázis amely megváltoztatja a szilárd test összetételét.

Az átalakulási feszültségek annak következtében keletkeznek, hegy a különböző fázısoknak más és más a sủrüségük. Például edzés folyamán az acélban $y \rightarrow \alpha^{\prime}$ átalakulás megy végbe, tehát az ausztenit átalakul 
martenzitté. Minden karbontartalmú vasötvözet fajtérfogata ausztenutes állapotban a legkisebb, perlıtes állapotban nagyobb és martenzites állapotban a legnagyobb. Tehát edzéskor az acél fajtérfogata növekszik, amely növekedést az okozza, hogy a rácsátalakulás következtében a karbon atomok interszticiósan bennmaradnak a rácsban, gyors hứtés miatt diffúzıómentes a folyamat és ezek az atomok feszitik a rácsot. A 3. ábrán látható, hogy $20 \mathrm{mp}$-nél a martenzites átalakulás okozta feszültségcsúcs ébred. Ezen átalakulás következtében a folyási feszültség a felületen (kéregben) nagymértékben megnő, az ausztenites szövetszerkezetü maghoz képest. Masrészrōl ez a plusz térfogatbeli változás a magnak képlékeny hossznövekedését eredményezi a kéreghez képest. Továbbá látható, hogy $40 \mathrm{mp}$-nél a martenzites átalakulás megkezdödik a magban is ami méretnövekedéssel jár, tehát a mag mérete növekszik és a magban a húzófeszültségek csökkennek. A magnak magas hömérsékleten végbement képlékeny növekedése a kéreghez képest $20^{\circ} \mathrm{C}$ - on a magban nyomó maradó-, a kéregben pedig húzó maradó feszültséget eredményez. Ez az axiális maradó feszültségek egy tipikus eloszlását mutatja $30 \mathrm{~mm}$ átméröjủ teljesen átedzett darabban, a 4. ábrán látható hửésnek megfelelően. [1]

$\mathrm{Az}$ ötvözetlen acélok magasabb hömèrsékleten alakulnak át. Itt az acèl képlékenyebb, a fázisátalakulás okozta feszültségek nagy része alakváltozással ki tud egyenlítődni. Az Ms-Mf hômérséklet függ az acél karbontartalmától. A feszültségı állapot a fentiektől eltérōen alakul, ha a munkadarab felületi rétege dekarbonizálódott vagy cementálódott (eltérő hőtágulási együttható és Ms hömérséklet).

Amennyiben egy 200 mm-es acélhengeren 20\%-os elōzetes képlékeny alakváltozást idézünk elö, az edzés után visszamaradó, tengelyirányú feszültségek alakulását összevetve az alakitatlan edzett henger feszültségeloszlásával, lényeges különbsegeket észlelünk [2]. Ezt szemlélteti az 5. ábra.
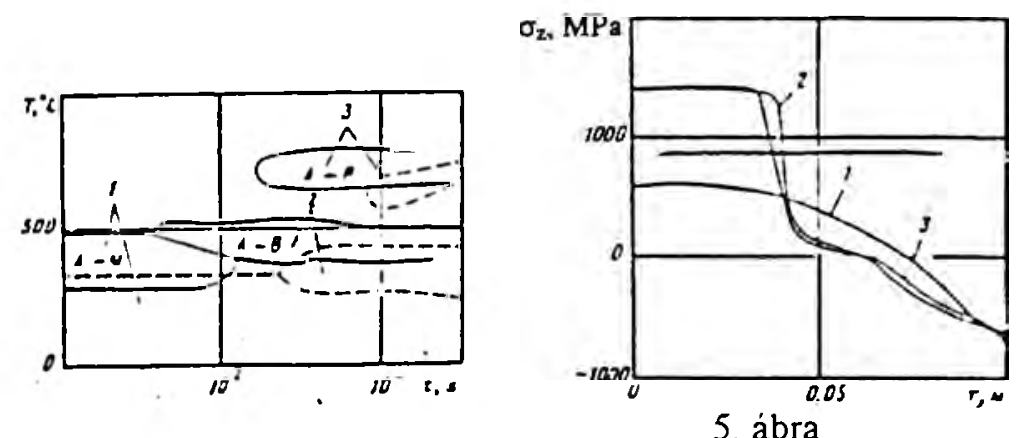

1. alakitatlan edzett

2. alakitott edzett

Hütési sebesség 0.02 fok $/ \mathrm{mp}$

3. alakitatlan edzett

Hütési sebesség 0.057 fok $/ \mathrm{mp}$.

Az acél átalakulási diagramjából jól kivehető, hogy alakitatlan esetben (folytonos vonal) a $0.02 \mathrm{fok} / \mathrm{mp}$ hütési sebesség esetén a perlites szövet megjelenik a darabban, mig az alakitott darabban (szaggatott vonal) bénites átalakulás megy végbe, tehát a feszültségcsúcs nagyobb lesz.

Régebben a maradó feszültségek és a vetemedés tanulmányozását túlnyomórész kisérleti úton végezték, amely módszerek sok idöt és munkabefektetést igényeltek. Ezáltal nagyon nehéz volt a különbözö befolyásoló tényezők hatásának az elörejelzése mivel ez a tanulmányozás eredményén alapult. Ezzel szemben a számitógépes módszerek lehetővé teszik, hogy a befolyásoló tényezök változásának figyelembevételével tanulmányozzuk a folyamatot, előre jelezve ezek hatását. Ehhez ismernünk kell az illető anyag tulajdonságait a kezdeti szakaszban, valamint a peremfeltételeket. Amint láttuk az acél alkatrészek 
edzésekor fázisátalakulások játszódnak le a darabban. A hőmérséklet változás hatására végbemenő térfogati tágulások, valamint az ezt követő átalakulások figyelembe vételével modellezni lehet az edzési folyamatokat [3]. A modellezéshez szükséges a hőmérséklet-, feszültségeloszlás és az átalakulás tanulmányozása.

Hengeres alkatrészek méretének belső feszültséget befolyásoló hatását vizsgálja, valamint az átalakulás folyamatát közelítő egyenlettel leírja Toshioka [4].

Hőeloszlás az acélhengerben edzés alatt:

$$
\begin{array}{ll}
T_{r}= & T_{0}+B\left(\frac{r}{R}\right)^{2} \quad \text { (1) [4] } \\
\mathrm{T}_{0} & \text { - hömérséklet a henger közepén }\left({ }^{\circ} \mathrm{C}\right) \\
\mathrm{T}_{\mathrm{r}} & \text { - hömérséklet a henger közepétől } \mathrm{r} \text { távolságra }\left({ }^{\circ} \mathrm{C}\right) \\
\mathrm{B} & \text { - hömérséklet gradiens tényező } \\
(\mathrm{r} / \mathrm{R})^{2} & \text { - pozícióparaméter }
\end{array}
$$

Az átalakulás folyamata:

$$
\begin{aligned}
& \varepsilon=\Delta \varepsilon\left\{1-\left(\frac{T-T_{f}}{T_{s}-T_{f}}\right)^{2}\right. \\
& \varepsilon \quad \text { - alakváltozás edzés közben }(\mathrm{mm} / \mathrm{mm}) \\
& \Delta \varepsilon \quad-\text { az átalakulást követő összes alakváltozás }(\mathrm{mm} / \mathrm{mm}) \\
& \mathrm{T}_{\mathrm{a}} \quad \text { - a martenzites átalakulás kezdeti hőmérséklete }\left({ }^{\circ} \mathrm{C}\right) \\
& \mathrm{T}_{\mathrm{f}} \quad \text { - a martenzites átalakulás végső hőmérséklete }\left({ }^{\circ} \mathrm{C}\right)
\end{aligned}
$$

Az edzési folyamatok számítógépes modellezésével kapcsolatban számos kutatási eredmény áll rendelkezésre. A vizsgálatok különböző hőkezelési eljárások különböző összetételủ, alakú és méretũ darabok esetén mutatják be a végsỏ szövetszerkezet kialakulását, a belső feszültségek eloszlását a darabban és a deformáció, vetemedés mértékét [2][3][5]. A következő ábra mutatja edzés során a fizikai mennyiségek és szövetszerkezeti változások kapcsolatát:

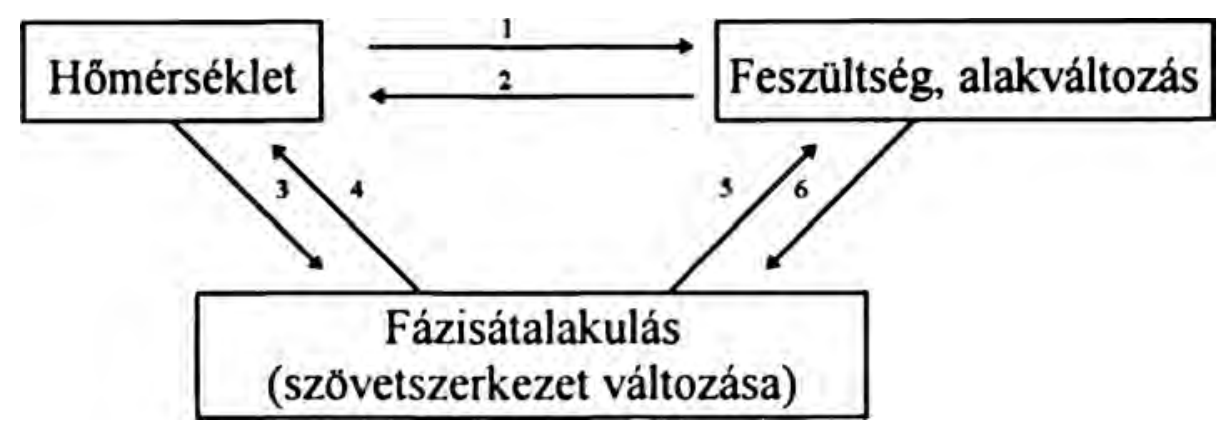

1. hőfeszültségek,

2. a deformáció eredményezte hő̃termelések, 
3. hőfokfuggő fázisátalakulások,

4. fázisátalakulás eredményezte hőtermelések,

5. fázisátalakulás eredményezte térfogati tágulások,

6. feszültségfüggő fázisátalakulások.

Az elemzések figyelembe veszik a hömérséklettől és a szerkezettől való függőséget, valamint a hőtermeléseket is. A deformációt követő hőtermelés egyes irodalmak szerint elhanyagolható [2].

A GAMF Mechanikai Technológiai Tanszéke több éve foglalkozik szerkezeti és szerszámacélok edzési méretváltozásának vizsgálatával. Az elvégzett kísérletek eredményei [6] is azt mutatják, hogy a méretváltozás, vetemedés, feszültségek - az átalakulási viselkedéseken, a szövetszerkezeti változásokon kereszül - csak bonyolult egymásra hatással, kapcsolatrenıdszerben kezelhetők, figyelembe véve a munkadarab használati tulajdonságait is. A doktori kutatásom része a belső feszültségek tanulmányozása, az edzési méretváltozások előrejelzése. Napjainkban már elterjedtek azok a végeselemes számítógépes programok, amelyek segítségével meghatározható a fázisátalakulás okozta feszültségek eloszlása, azonban a modellezés során nehézségek adódnak az említett bonyolult kapcsolatrendszer, valamint a befolyásoló tényezők hatásának leírásában. Tehát munkám során próbálkozom bevinni a modellezésbe a lehető legtöbb befolyásoló tényező által kifejtett hatást, mert ezáltal a számított valamint a kísérlettel kapott eredmények között kisebb lesz az eltérés és lehetővé válik a méretváltozás pontosabb előrejelzése.

\section{Felhasznált irodalom:}

[1] STEEL: A handbook for Materials Research and engineering

[2] S. Kamamoto, T.Nishimori, S.Kinoshita: Analysis of residual stress and distortion resulting from quenching in large low-alloy steel shafts. Material Science and Technology, October 1985 Vol. 1.

[3] D. Pont, J.M. Bergheau: Numerical determination of residual stresses induced by laser surface treatments. Institut de Sudure, France.

[4] Toshioka Y.: Calculation of Internal Stress of Steel Induced during Quenching. Transactions ISIJ, vol.12, 1972

[5] S. Ray: Study of residual stresses in welding. Indian Welding Journal, 1984 IV/2/16.

[6] Fazekasné dr. Berta Mária, Johanyák Edit: Méretváltozás edzésnél microCAD 94 Informatikai Nemzetközi Konferencia, Miskolc 1994, Konferencia Kiadvány, 9-17 old.

Johanyák Edit tud. s. munkatárs

Gépipari és Automatizálási Mữszaki Föiskola

Mechanikai Technológiai Tanszék

6000 Kecskemét, Izsáki út 10, Magyarország

Tel.: 003676481291 , Fax: 003676481304 